\title{
Nötrositik asitli siroz hastalarında serum ve asit sıvısı TNF-alfa, interlökin-6, nitrik oksit ve myeloperoksidaz seviyelerinin, asit enfeksiyonu açısından tanısal ve prediktif değeri
}

\author{
Diagnostic and predictive values of serum and acid fluid TNF-alpha, interleukin-6, nitric oxide, \\ and myeloperoxidase in patients with neutrocytic acid cirrhosis
}

\author{
(D) Ferda AKBAY HARMANDAR ${ }^{1}$, (D) Orbay HARMANDAR ${ }^{2}$, (D)Ahmet TEZEL ${ }^{3}$ \\ Sağlık Bilimleri Üniversitesi, Antalya Eğitim ve Araştırma Hastanesi, İç Hastalıkları Anabilim Dalı, 'Gastroenteroloji Bilim Dalı, \\ ${ }^{2}$ Yoğun Bakım Bilim Dalı, Antalya
}

Trakya Üniversitesi Tıp Fakültesi İç Hastalıkları Anabilim Dalı, ${ }^{3}$ Gastroenteroloji Bilim Dalı, Edirne

\begin{abstract}
Giriş ve Amaç: Asitli siroz hastalarında ortaya çıkan spontan asit enfeksiyonu, mortalitesi yüksek bir komplikasyondur. Çalısmamızda, spontan asit enfeksiyonu sırasında, proinflamatuvar sitokinler olan interlökin-6 ve tümör nekrozis faktör-alfanın asit sIVIsı ve serumda, nitrik oksit ve myeloperoksidazın ise asit sıvısındaki düzeylerine bakıp, bu sonuçların asit enfeksiyonu açısından tanısal ve prediktif değeri olup olmadığını araştırdık. Gereç ve Yöntem: Çalışmaya alınan 40 hasta, steril asitli grup, kültür negatif nötrositik asitli grup ve spontan bakteriyel peritonitli grup olarak ayrıldı. Hastalardan başvuru anında asit sIVISI ve serum örnekleri alınarak saklandı. Daha sonra tüm olguların asit sIVIsı ve serumunda immünoradyometrik yöntemle interlökin-6 ve tümör nekrozis faktör-alfa, asit sIvilarında ELISA ile myeloperoksidaz ve enzimatik yöntemle nitrik oksit düzeyleri çalışılarak üç grup birbiriyle ayrı ayrı karşılaştıııldı. Bulgular: Olguların asit sIvISı ve serum interlökin-6 düzeyi ortalaması kültür negatif nötrositik asit ve spontan bakteriyel peritonit grubunda steril asit grubundan anlamlı derecede yüksek bulunmuştur. Asit sIVISı tümör nekrozis faktör-alfa düzeyi ortalaması spontan bakteriyel peritonit grubunda steril asit grubuna kıyasla anlamlı derecede yüksek saptanırken, serum tümör nekrozis faktör-alfa düzeyi ortalamasında her üç grup arasında istatistiksel anlamlı fark saptanmamışır. Asit sIVISı myeloperoksidaz düzeyi ortalaması kültür negatif nötrositik asit ve spontan bakteriyel peritonit grubunda steril asit grubundan anlamlı derecede yüksek bulunmuştur. Asit sIVIsı nitrik oksit düzeyi ortalaması arasında ise her üç grup arasında istatistiksel anlamlı fark saptanmamıştır. Sonuç: Elde edilen bulgular, asitli siroz hastalarında, spontan asit enfeksiyonu tanısında, asit sIvIsı ve serumdaki interlökin-6 ile asitteki myeloperoksidaz düzeylerinin, konvansiyonel yöntemlere yardıma olabileceğini, nitrik oksit ve tümör nekrozis faktör-alfa değerlerinin ise tanısal açıdan uygun olmadığını düşündürmektedir.
\end{abstract}

Anahtar kelimeler: Asit, interlökin-6, tümör nekrozis faktör-alfa, nitrik oksit, myeloperoksidaz.
Background and Aims: Spontaneous acid infection in patients with acidic cirrhosis is a complication with a high mortality rate. This study aimed to investigate the acid fluid and serum levels of proinflammatory cytokines interleukin-6 and tumor necrosis factor-alpha and acid fluid levels of nitric oxide and myeloperoxidase during spontaneous acid infection and to identify their diagnostic and predictive applicability with regard to acid cirrhosis. Materials and methods: We included 40 patients and categorized them into the following three groups: sterile acid, culture-negative neutrocytic acid, and spontaneous bacterial peritonitis. Acid fluid and serum samples were collected from patients upon admission and then stored. In all cases, acid fluid and serum levels of interleukin-6 and tumor necrosis factor-alpha were investigated by immunoradiometric method, acid fluid levels of myeloperoxidase by ELISA method, and nitric oxide levels by enzymatic method. Subsequently, these three groups were compared with each other. Results: Serum and acid fluid levels of interleukin-6 were significantly lower in the sterile acid group than in the culture-negative neutrocytic acid and spontaneous bacterial peritonitis groups. Serum interleukin-6 levels in the culture-negative neutrocytic acid and spontaneous bacterial peritonitis groups were significantly higher than those in the sterile acid group. Moreover, the acid fluid and serum tumor necrosis factor-alpha levels in the culture-negative neutrocytic acid group were significantly higher than those in the sterile acid group; however, there was no statistical difference in the intergroup serum tumor necrosis factor-alpha levels. The acid fluid levels of myeloperoxidase were also significantly higher in the sterile acid group than in the culture-negative neutrocytic acid group and spontaneous bacterial peritonitis group. We observed no significant intergroup differences with regard to the nitric oxide levels in acid fluid. Conclusion: In chronic liver parenchyma patients with neutrocytic acid cirrhosis, acid fluid and serum levels of interleukin-6 and acid fluid levels of myeloperoxidase may help the conventional methods in diagnosing spontaneous acid infection; however, the serum levels of nitric oxide and tumor necrosis factor-alpha have no diagnostic value.

Key words: Ascite, interleukin-6, tumor necrosis factor-alpha, nitric oxide, myeloperoxidase.
Iletişim: Ferda AKBAY HARMANDAR

S. B. Üniversitesi Antalya Eğitim ve Araştırma Hastanesi, Gastroenteroloji Kliniği, Kazım Karabekir Caddesi, Muratpaşa, Antalya

E-mail: harmandarferda@gmail.com
Akbay Harmandar F, Harmandar O, Tezel A. Diagnostic and predictive values of serum and acid fluid TNF-alpha, interleukin-6, nitric oxide, and myeloperoxidase in patients with neutrocytic acid cirrhosis. The Turkish Journal of Academic Gastroenterology 2020;19:75-82. DOI: 10.17941/agd.799360

Geliş Tarihi: 14.07.2020 • Kabul Tarihi: 25.08.2020 


\section{GíRiş}

Siroz, karaciğerin normal parankim dokusunun kaybı, bağ dokusunun artışı, rejenerasyon nodüllerinin oluşması ve vasküler yapının bozulması ile karakterize, kronik, ilerleyici bir karaciğer patolojisidir. Sirozlu hastalarda, asit sIVISI enfeksiyonu sık rastlanan (\%10-25), ciddi bir komplikasyondur ve \%30-50 oranında bir mortaliteyle seyreder (1). Spontan bakteriyel peritonit (SBP) [asit polimorfonükleer lökosit (PNL) sayısı > 250/ $\mathrm{mm}^{3}$ ve pozitif asit kültürü olması] ve kültür negatif nötrositik asit tablosu (KNNA) [Asit sıvısında polimorfonükleer lökosit sayısının $\mathrm{mm}^{3}$ te 250 ve üstünde olması] en sık tanımlanan varyantlar olup, sadece kültürde üremenin saptandığı fakat PNL sayısı 250/mm3'ü geçmeyen monomikrobik "nonnötrositik" bakterasit (MNB) tablosu da bir diğer alt gurubu oluşturur (2). Klasik SBP tanısı yanında, mevcut kültür teknikleri ile tespit edilemeyecek kadar düşük bakteri konsantrasyonu nedeniyle sıklıkla ortaya çıkan KNNA tablosu, klinik açıdan büyük önem taşımaktadır.

Makrofajlar tarafından üretilen intraperitonal faktörler [nitrik oksit (NO), interlökin-6 (IL-6), tümör nekrozis faktör- $\alpha(T N F-\alpha)$ ], bakteriler veya onların ürünlerinin varlı̆̆ının, serum veya asit sıvısında enfeksiyonun indirekt belirteçlerini oluşturabilirler. Sitokinlerden, özellikle TNF- $\alpha$ ve IL-6 bu inflamatuvar yanıtın başlıca medyatörleridir $(3,4)$. Nötrofiller ve monositler bakterilerin öldürülmesi için, hem oksijen bağımlı hem de oksijenden bağımsız mekanizmaları kullanırlar. Oksijen bağımlı mekanizmalar, myeloperoksidaz (MPO) sistemini ve oksijen türevi serbest radikallerin üretimini sağlayan bir başka sistemi içerirler. MPO, nötrofiller ve monositlerde eksprese edilen bir hem proteini olup, bu hücrelerin aktivasyonu sırasında sekrete edilir Yukarıdaki bilgiler ışığında çalışmamızda, asitli siroz hastalarında, asit sIVIsında TNF- $\alpha$, IL-6, NO ve MPO, serumda TNF- $\alpha$ ve IL- 6 seviyelerine bakarak, elde edilecek olan veriler doğrultusunda, kültür negatif nötrositik asitli hasta grubuyla, spontan bakteriyel peritonitli ve steril asitli hasta gruplarını ayrı ayrı karşılaştırmayı, daha sonra adı geçen moleküllerin, asit sıvısı enfeksiyonuyla ilgili tanısal ve prediktif değerlerini araştırmayı amaçladık.

\section{GEREÇ ve YÖNTEM}

Çalışmamıza, Trakya Üniversitesi Tıp Fakültesi Gastroenteroloji Bilim Dalı Kliniği'nde dekompanse/asitli kronik karaciğer parankim hastalığı tanısıyla izlenen hastalar dahil edildi. Çalışmamıza Trakya Üniversitesi Tıp Fakültesi Etik Kurulundan onay alındı (06.07.2006/11) ve çalışmaya dahil edilen her hastaya, çalışma hakkında bilgi veren ve hastanın rızasının alındığııı belgeleyen "Bilgilendirilmiş Olur Formu" imzalatıldı. Asitli olgular, steril asitli grup (grup 1), KNNA grubu (grup 2) ve SBP grubu (grup 3) olarak belirlendi. Toplam 40 olgunun, 25'i steril asitli grupta, $10^{\prime}$ u kültür negatif nötrositik asitli grupta ve 5 tanesi SBP'li gruptaydı. Steril asitli grubuna asitteki PNL sayısı < $250 / \mathrm{mm}^{3}$ saptanıp asit sıvısı kültüründe üreme olmayanlar, KNNA grubuna asitte PNL sayısı > 250/mm³ olup, kültürde üreme olmayanlar dahil edilirken SBP grubuna ise asit sIVIsında PNL sayısı $>250 / \mathrm{mm}^{3}$ olup asit kültüründe üreme olanlar alındı. Hastaların tanısı klinik, laboratuvar, görüntüleme ve histokimyasal bulgular ile konuldu. Bütün hastalara yatışından hemen sonra abdominal parasentez yapıldı. Barsak perforasyonu varlığı, intraabdominal kaynaklı enfeksiyon varlığı, periton tüberkülozu şüphesi olanlar, pankreatit, peritoneal karsinamatozis, hemorajik ve şilöz asiti bulunan hastalar çalışmaya alınmadı. Hasta grupları oluşturulurken, kan kültürlerinde üreme olmamasına ve spontan bakteriyel peritonit dışında herhangi bir enfeksiyon olmamasına dikkat edildi. Hastalardan, antibiyoterapi başlanmadan önce alınan asit sıvısı ve serum örnekleri, 3000 devir/dk'da 5 dakika santrifüj edilip, NO açısından arındırımış epandorflara konularak $-85^{\circ} \mathrm{C}^{\prime} \mathrm{de}$ saklandı. IL-6 ve TNF- $\alpha$ ölçümü için, serum ve asit materyallerinden antikor karışımı elde edilerek Gamma Counter cihazında sayım yapıldı.

Nitrik oksitin biyolojik sıvılardaki yarı ömrü çok kısadır ve hızla stabil metaboliti olan nitrat ve nitrite dönüşür. Bundan dolayı NO tayini nitrat ve nitrit konsantrasyonları saptanarak yapılmaktadır. Nitrik oksit analizi Cortas ve arkadaşlarının (5) tanımladıkları metoda göre spektrofotometrik (Shimadzu UV-1700, Japonya) olarak yapıldı. Asit sıvısı MPO düzeyleri çift sandiviç enzim linked immunusorbent assay (ELISA) yöntemi ile ölçüldü.

\section{İstatiksel Değerlendirme}

İstatistiksel çalışmada farklı gruplara ilişkin verilerin karşılaştırımasında, normal dağılıma uyan değişkenler için One-way ANOVA testi uygulandıktan sonra, her grup birbiriyle Tukey testi ile karşılaştıııldı. Asitteki TNF- $\alpha$ düzeyleri ise, normal dağılıma uymadığı için gruplar arasında Kruskal-Wallis testi yapıldı ve daha sonra $2^{\prime} l i$ grup Mann-Whitney U testi ile karşılaştırılı. Değişkenlerin birbiriyle ilişkilerinin belirlenmesi için, Pearson korelasyon testi, aynı grup içerisindeki parametrelerin karşılaştırılmasında eşlenmiş $\mathrm{t}$ testi kullanıldı. Anlamlı tespit edilen parametrelerde, prediktivitenin hesaplanmasında "ROC curve" analizi yapıldı. Çalışmamızda, istatistiksel anlamlılık sınırı olarak $p<0.05$ değeri esas alındı. Çoklu grupların karşılaştırımasında Bonferroni düzeltmesi yapılarak anlamlıık sınırının tesbitinde, $p=0.05$ değeri grup sayısı olan $3^{\prime}$ e bölündü ve $p<$ 0.017 değeri saptandı ve çoklu grupların karşılaştırmasında $p<0.017$ değeri istatistiksel anlamlı kabul edildi. 


\section{BULGULAR}

Çalışmaya alınan 40 olgunun, 25'i (4 kadın, 21 erkek) steril asit grubunda, 10'u (4 kadın, 6 erkek) kültür negatif nötrositik asit grubunda ve 5'i (1 kadın, 4 erkek) ise spontan bakteriyel peritonit grubundaydı. Hastaların yaşları 23-83 arasında değişmekte olup, yaş ortalamaları $56.5 \pm 12.7$ şeklindeydi ve gruplar arasında anlamlı bir farkllık yoktu ( $p=0.925)$ (Tablo 1).

Hastaları Child-Turcotte-Pugh kriterlerine göre sınıflandırdığımızda, steril asitli gruptaki 25 hastanın, 12'sinin Child B, 13 tanesinin Child C'ye, KNNA'I gruptaki 10 hastadan 4'ünün Child B ve 6 tanesinin Child C'ye ve SBP grubundaki 5 hastanın tümünün Child $C$ grubuna dahil olduğunu saptadık (Tablo 1).

Spontan bakteriyel peritonitli 5 hastanın, 3'ünde gram negatif basil ve 2'sinde gram pozitif kok üremesi saptandı. Tüm parametreler (IL-6 asit, IL-6 serum, TNF- $\alpha$ asit, TNF- $\alpha$ serum, NO asit ve MPO asit) açısından karşılaştırdığımızda üç grup arasında fark olduğu görüldü (Tablo 2).
Serum ve asitteki IL-6 düzeyleri açısından, her grubu birbiri arasında ayrı ayrı karşılaştırdığımızda, grup 1 'in asit sIVIsındaki IL-6 ortalamasının hem grup 2, hem de grup 3 ortalamasından anlamlı derecede $(p=0.001)$ düşük olduğu saptandı. Grup 2 ve grup 3 arasında ise istatistiksel olarak fark yoktu ( $p=0.915)$. Yine serumdaki IL-6 düzeyleri açısından değerlendirildiğinde de, benzer bulgular karşımıza çıkmış olup, grup 2 ve grup 3'ün IL-6 ortalamaları, grup 1'den anlamlı olarak yüksek ( $\mathrm{p}=0.001)$ iken, birbirleri arasında (grup 2 ve 3 ) anlamlı bir fark saptanmadı $(p=0.129)$ (Tablo 3)

Asit IL-6 düzeyini, spontan asit enfeksiyonu açısından değerlendirdiğimizde, duyarlıığını \%100, özgüllüğünü \%60 ve pozitif prediktif değerini \%26.3 olarak (cut-off değeri $>2718.07 \mathrm{pg} / \mathrm{ml}$ ) saptadık. Serum IL-6 seviyesi için aynı analizi yaptığımızda, testin özgüllüğünün \%80 olduğu durumda duyarlıı̆ının \%100 (cut-off değeri > 352.41 $\mathrm{pg} / \mathrm{ml}$ ) ve pozitif prediktif değerinin \%41.7 olduğunu gördük.

\begin{tabular}{|c|c|c|c|}
\hline & Steril Asit & KNNA & SBP \\
\hline$N(K / E)$ & $25(4 / 21)$ & $10(4 / 6)$ & $5(1 / 4)$ \\
\hline Yaş & $57 \pm 13$ & $56 \pm 11$ & $54 \pm 14$ \\
\hline \multicolumn{4}{|l|}{ Etiyoloji } \\
\hline HBV & $11(\% 44)$ & $2(\% 20)$ & $2(\% 40)$ \\
\hline $\mathrm{HCV}$ & $2(\% 8)$ & $1(\% 10)$ & - \\
\hline Etanol & $6(\% 24)$ & $3(\% 30)$ & $2(\% 40)$ \\
\hline Kriptojenik & $2(\% 8)$ & $4(\% 40)$ & $1(\% 20)$ \\
\hline Metabolik & $1(\% 4)$ & - & - \\
\hline HBV+Etanol & $2(\% 8)$ & - & - \\
\hline HCV+Etanol & $1(\% 4)$ & - & - \\
\hline Child (B/C) & $(12 / 13)$ & $(4 / 6)$ & $(0 / 5)$ \\
\hline
\end{tabular}

KNNA: Kültür negatif nötrositik asit; SBP: Spontan bakteriyel peritonit; HBV: Hepatit B virüsü; HCV: Hepatit C virüsü.

Sonuçlar ortalama \pm SD şeklinde verilmiştir. Grupların karşılaştırılmasında tek yönlü varyans analizi kullanılmıştır.

Tablo 2. Grupların IL-6, TNF- $\alpha$, NO ve MPO seviyeleri

\begin{tabular}{|lcccc|}
\hline & Steril Asit & KNNA & SBP & p* \\
\hline IL-6 asit $(\mathrm{pg} / \mathrm{ml})$ & $2271.44 \pm 788.32$ & $3679.39 \pm 815.92$ & $3857.10 \pm 905.34$ & 0.001 \\
\hline IL-6 serum $(\mathrm{pg} / \mathrm{ml})$ & $218.77 \pm 66.27$ & $832.24 \pm 781.96$ & $1880.75 \pm 1429.83$ & 0.001 \\
\hline TNF- $\alpha$ asit $(\mathrm{pg} / \mathrm{ml})$ & $102.20 \pm 131.24$ & $122.47 \pm 128.14$ & $765.96 \pm 857.42$ & 0.017 \\
\hline TNF- $\alpha$ serum $(\mathrm{pg} / \mathrm{ml})$ & $46.12 \pm 21.06$ & $83.36 \pm 76.07$ & $170.09 \pm 251.81$ & 0.030 \\
\hline NO asit $(\mu \mathrm{mol} / \mathrm{L})$ & $70.074 \pm 20.75$ & $150.75 \pm 162.84$ & $86.34 \pm 47.63$ & 0.046 \\
\hline MPO asit $(\mathrm{ng} / \mathrm{ml})$ & $23.43 \pm 11.16$ & $44.00 \pm 12.82$ & $55.70 \pm 4.02$ & 0.001
\end{tabular}

KNNA: Kültür negatif nötrositik asit; SBP: Spontan bakteriyel peritonit; IL-6: Interlökin 6; TNF- $\alpha$ : Tümör nekrozis faktör alfa; NO: Nitrik oksit; MPO: Myeloperoksidaz. Oneway-ANOVA, * $p<0.05$ (TNF- $\alpha$ asit, normal dağılıma uymadığı için Kruskal-Wallis kullanılmıştır.) 


\section{Tablo 3. IL-6, TNF- $\alpha$, MPO ve NO seviyelerinin gruplar arası karşılaştırılması- $p$ değerleri}

\begin{tabular}{|lcccccc|} 
Karşılaştırılan Gruplar & $\begin{array}{c}\text { IL-6 } \\
\text { Asit }\end{array}$ & $\begin{array}{c}\text { IL-6 } \\
\text { Serum }\end{array}$ & $\begin{array}{c}\text { TNF- } \alpha \\
\text { Asit }\end{array}$ & $\begin{array}{c}\text { TNF- } \alpha \\
\text { Serum }\end{array}$ & $\begin{array}{c}\text { MPO } \\
\text { Asit }\end{array}$ & $\begin{array}{c}\text { NO } \\
\text { Asit }\end{array}$ \\
\hline Grup 1-Grup 2 & 0.001 & 0.001 & 0.627 & 0.535 & 0.001 & 0.036 \\
\hline Grup 1-Grup 3 & 0.001 & 0.001 & 0.003 & 0.025 & 0.001 & 0.917 \\
\hline Grup 2-Grup 3 & 0.915 & 0.129 & 0.028 & 0.214 & 0.145 & 0.347
\end{tabular}

KNNA: Kültür negatif nötrositik asit; SBP: Spontan bakteriyel peritonit; IL-6: Interlökin 6; TNF- $\alpha$ : Tümör nekrozis faktör alfa; NO: Nitrik oksit; MPO: Myeloperoksidaz. Tukey Test (TNF- $\alpha$ asit karşılaştırılmasında Mann-Whitney U testi kullanılmıştır). (istatistiksel anlamlılık $p<0.017$ )

Tüm grupların asit ve serum TNF- $\alpha$ düzeylerine bakıldığı zaman, grup 3'ün asitteki TNF- $\alpha$ düzeyinin, grup 1'e göre anlamlı yüksek çıktı̆̆ı görülürken ( $p=0.003)$, grup 2 ile 1 ve 3. gruplar arasında anlamlı bir fark saptanmadı (sırasıly $p=0.627, p=0.028$ ). Serumdaki TNF- $\alpha$ seviyeleri ise hiçbir grup arasında istatistiksel anlamda bir farklılık göstermiyordu $(p=0.535, p=0.025, p=0.214)(p<0.017)$ (Tablo 3).

Asit sıvısı MPO düzeyleri değerlendirildiğinde, hem 2 hem 3. gruptaki ortalamalar, 1. grupla karşış̧ı̧ıııldı̆ında, steril asitli gruba göre diğer iki grupta anlamlı bir yükseklik saptandı (her iki kıyaslama için $p=0.001$ ). Grup 2 ve grup 3 arasında ise belirgin bir fark yoktu ( $p=0.145$ ) (Tablo 3 ). Bu sonuçları tanısal açıdan değerlendirdiğimizde, asit sıvlsı MPO düzeyinin duyarlıı̆ının \%100 iken özgüllüğünün \%85 ve pozitif prediktif değerinin \%50 olduğunu saptadık (cut-off değeri > $46 \mathrm{ng} / \mathrm{ml}$ ).

Yine asit sıvısında bakılan NO seviyeleri karşılaştıııldığında ise, steril asitli grupla, 2. ve 3. grup arasında anlamlı bir fark saptanmadığı (sırasıyla $p=0.036$ ve $p=0.917$ ) gibi, KNNA grubu ile SBP grubu arasında da belirgin bir fark bulunmuyordu ( $p=0.347$ ) (Tablo 3).

Asit sIVIsındaki IL-6 seviyesi ile serumdaki IL-6 seviyesini karşılaştırdığımız zaman, her 3 grupta da asitteki ortalamanın, belirgin olarak serumdakinden daha yüksek olduğunu gördük (sırasıyla $p=0.001, p=0.001, p=0.003$ ). Aynı karşılaştırmayı TNF- $\alpha$ için yaptığımızda ise yalnızca steril asitli grupta (grup 1), asit sIvisındaki TNF- $\alpha$ seviyesinin, serumdakine göre anlamlı bir yükseklik taşıdığını saptadık $(p=0.034)$.

Çalışmaya alınan 40 olguda, araştırılan bütün parametreleri karaciğer hastalığının şiddeti açısından değerlendirdiğimizde, asit sıvısındaki NO seviyesi hariç tüm parametrelerin ortalama değerlerinin, Child C grubunda (24 hasta), Child B grubuna (16 hasta) göre daha yüksek olduğunu fakat bu yüksekliğin istatistiksel olarak hiçbirinde anlam ifade etmediğini gördük $(p>0.05)$. Asitteki NO düzeyinin ise, Child B grubunda daha yüksek olduğunu saptamamıza rağmen, bu fark anlam taşımıyordu $(p=0.353)$
Farklı parametrelerin birbirleriyle ilişkilerini her grupta ayrı ayrı incelediğimizde, steril asitli grupta, asit sıvısındaki ve serumdaki TNF- $\alpha$ değerlerinin birbiriyle doğru orantılı olduğunu gördük ve bu korelasyon da istatistiksel olarak anlamlıydı $(r=0.396, p<0.05)$. Yine aynı grubun asit sıvısındaki MPO ile IL-6 seviyeleri de anlamlı bir ilişki taşımaktaydı $(r=0.411, p<0.05)$. KNNA'lı grubu incelediğimizde ise, serumdaki IL- 6 ve asitteki TNF- $\alpha$ seviyesi arasında anlamlı bir korelasyon ( $r=0.815, p<0.01)$ karşımıza çıkarken aynı şekilde asit sıvısındaki NO seviyesi ile serumdaki TNF- $\alpha$ seviyesi arasında da benzer bir ilişki mevcuttu $(r=0.944, p<0.01)$. SBP'li grupta (grup 3$)$ ise istatistiksel olarak anlamlı bir korelasyon, hem asitteki ve serumdaki IL-6 düzeyleri arasında $(r=0.926, p<0.05)$, hem de asitteki ve serumdaki TNF- $\alpha$ düzeyleri arasında $(r=0.948, p<$ 0.05) saptandı.

\section{TARTIŞMA}

Sirozun tedavisinde dekompanse dönemde hayatı tehdit edici komplikasyonlarla mücadele ön plana geçer. Bu komplikasyonlardan biri, belki de en önemlisi spontan asit enfeksiyonudur. Sirozlu hastalarda, asit sivisı enfeksiyonu sık rastlanan (\%10-25), ciddi bir komplikasyondur ve \%30-50 oranında bir mortaliteyle seyreder (1). SBP (asit PNL sayısı $>250 / \mathrm{mm}^{3}$ ve pozitif asit kültürü olması) ve KNNA (asit sıvısında polimorfonükleer lökosit sayısının $\mathrm{mm}^{\prime}$ te 250 ve üstünde olması) en sık tanımlanan varyantlardır (2). Mevcut kültür teknikleri ile tespit edilemeyecek kadar düşük bakteri konsantrasyonu nedeniyle ortaya çıkan KNNA tablosu, klinik açıdan büyük önem taşımakta olup, derhal tedavi başlanmasını gerektiren bir durumdur.

Spontan asit enfeksiyonu olan hastalarda, IL-6 ve TNF- $\alpha$ 'yI içeren sitokin yolaklarında belirgin bir aktivasyon olduğu ilk defa Byl ve arkadaşları tarafından gösterilmiştir (6). Bununla birlikte NO'nun, sinerjik olarak çalışan farklı sitokinler tarafından indüklenebilir nitrik oksit sentaz (iNOS) yoluyla üretiminin tetiklendiği ileri sürülmüştür (7). Ayrıca kronik karaciğer parankim hastalığında sitokinlerin kliren- 
sinin azaldığı Tilg ve arkadaşları tarafından belirlenmiştir (8). Yine nötrofil ve monositlerin aktivasyonu sırasında sekrete edilen MPO'nun da, sirozlu ve peritonitli deneklerde yapılan sınırlı sayıdaki çalışmalarda plazma ve asit sıvısındaki durumu araştırılmıştır $(9,10)$.

Dekompanse kronik karaciğer parankim hastalı̆̆ı tanısı ile izlenen asitli hastalarda yaptığımız çalışmada, söz konusu sitokinlerin asit sIVISI ve serumdaki seviyelerini, steril asitli, KNNA'I ve SBP'li gruplarda ayrı ayrı inceledik.

Interlökin-6, kaynağı T lenfositler, monositler, endotel hücreleri, fibroblastlar, stroma hücreleri ve tümör hücreleri olan bir çeşit proinflamatuvar sitokindir. Strassmann ve arkadaşları, IL-6'nın karaciğer kaynaklı akut faz reaktanlarını uyarmak için belirgin şekilde arttığını göstermişlerdir (11). Diğer taraftan, IL-6, adrenokortikotropik hormonu (ACTH) uyararak dolaşan kortizol düzeyinin arttırılması, monosit ve makrofajlardan nötrofillerin indüklediği interlökin-1 (IL-1) ve tümör nekrozis faktör (TNF) sentezinin azaltılması, reaktif oksijen ürünlerinin ve kısa ömürlü nitrojen ara ürünlerinin üretiminin azaltılması gibi etkilerinden dolayı antiinflamatuvar sitokinler arasında da gösterilmektedir (12). Anlaşıldığı üzere IL-6'nın inflamasyon üzerinde iki yönlü bir etkisi mevcuttur.

Çalışmamızda, serum ve asitteki IL-6 düzeyleri açısından her üç grubu birbirleri arasında ayrı ayrı karşılaştırdığımızda, hem serumdaki hem de asitteki değerlerin, steril asitli grupta, KNNA ve SBP grubuna göre anlamlı derecede düşük olduğunu gördük. KNNA ve SBP arasındaki kıyaslamada ise iki grup arasındaki asit sıvısı ve serumdaki IL-6 seviyeleri anlamlı bir farklılık göstermedi. Bunların yanında, asit enfeksiyonu tanısı açısından, asitteki IL-6 seviyesinin pozitif prediktif değeri \%26.3 (özgüllüğü \%60, duyarlıı̆̆ı \%100) iken serumdaki IL-6 seviyesinin pozitif prediktif değeri \%41.7 (özgüllüğü \%80, duyarlılı̆ı \%100) şeklindeydi.

Rodriguez-Ramos ve arkadaşları, sirozlu hastalarda yaptıkları çalışmada, bizim çalışmamıza benzer olarak, spontan asit enfeksiyonu bulunan grubun serum ve asit sIVIsındaki IL-6 seviyesini, steril asitli gruba göre daha fazla bulmakla beraber, SBP'li grubun değerlerini de, bizim sonuçlarımızdan farkı olarak, KNNA'lı gruptan anlamlı yüksek saptamışlardır. SBP'li grup ile KNNA'lı gruplar arasındaki bu farkın etken mikroorganizma konsantrasyonları ile ilişkili olabileceğini ileri sürmüşlerdir (13). Navasa ve arkadaşlarının da, yaptığı çalışmada benzer sonuçlar elde edilmiştir (14).

Bu çalışmalardan farklı olarak, Such ve arkadaşları, 2001 yılında yayınladıkları bir çalışmada, diğer yayınlardan farkIı sonuçlar raporlamışlardır. Bu çalışmada araştıııcılar, asitli siroz hastalarının serum ve asit sIvisında IL-6, TNF- $\alpha$ ve
NO düzeylerini ölçmüşler ve önceki çalışmalardan farklı olarak, spontan asit enfeksiyonu olan hastalarla steril asitli hasta grubu arasında IL-6 düzeyleri arasında istatistiksel bir fark elde edememişlerdir (15).

Bunlardan başka, hem Jimenez ve arkadaşları hem de Propst ve arkadaşları, yaptıkları çalışmalarda SBP'li hastaların asit sIVısındaki IL-6 seviyesinin, steril asitli siroz hastalarınınkinden anlamlı derecede yüksek bulmuşlardır $(16,17)$. Bizim çalışmamızda elde edilen bulgular bu çalışmalarla uyum içerisindeydi. Ayrıca Fransa ve Hollanda'da, asitli siroz hastalarında yapılan iki araştırmada da, SBP'li hastaların asit sıvısında IL-6 seviyesi, steril asitli grubunkinden anlamlı yüksek saptanmasına rağmen, aynı yükseklik, serumdaki IL-6 değerleri açısından incelendiğinde saptanamamıştır $(18,19)$.

Bu bulgular doğrultusunda çalışmamız, IL-6'nın, sirozlu hastalardaki asit enfeksiyonlarında, sitokin yolaklarının aktivasyonu sonucu artmış olduğu ve KNNA grubunda da SBP'ye benzer şekilde yüksek IL-6 düzeyleri saptanması nedeniyle, spontan asit enfeksiyonu tanısında asit IL-6 seviyelerinin kullanılabileceği ve önceki bir çalışmada (17) belirtildiği gibi asit enfeksiyonu açııından prognostik öneminin olabileceği düşüncelerini desteklemektedir. Kronik karaciğer parankim hastaları, bağışıklık sistemleri baskılanmış olduğu için asit enfeksiyonu yanında, alt ve üst solunum yolu enfeksiyonları, üriner sistem ve cilt enfeksiyonları gibi durumlara eğilimlidirler. Çalışmamızda elde edilen veriler de, IL-6'nın asit ve serumdaki düzeylerinin, asit enfeksiyonunu tespit etmede oldukça hassas (asitte ve serumda duyarlılık \%100) olmakla beraber, bu hastaların diğer enfeksiyonlara karşı artmış eğilimleri nedeniyle özgüllüğünün nispeten düşük olduğunu (asit için \%60, serum için \%80) göstermiştir, çünkü IL-6 birçok enfeksiyonda ortak sitokin yolağı elemanıdır.

Çalışmamızda, grupların asit ve serum IL-6 seviyelerini karşılaştırdığımızda, hem KNNA grubunda hem de SBP grubunda, asit sıvısındaki IL-6 değerinin, serumdakine göre belirgin yüksek olduğunu saptadık. Bu sonuçlar daha önceki araştırma sonuçları $(14,13)$ ile uyumluluk göstermekle beraber, çalışmamızda SBP'li grubun asit sıvısı ve serumundaki IL-6 seviyeleri arasında anlamlı bir korelasyon mevcuttu. Çalışmaya alınan olguları, karaciğer hastalığının şiddetine göre gruplayarak, bakılan parametreler açısından karşılaştırdığımızda, Child C ve Child B grupları arasında IL-6 seviyelerinin anlamlı bir fark oluşturmadığını gördük.

Tümör nekroz faktör- $\alpha$, çoğunlukla aktive makrofajlar, antijenle stimüle edilmiş $T$ hücreleri, aktive naturel killer (NK) ve mast hücrelerinden, daha az olarak da diğer hücrelerden salınır. TNF- $\alpha$, başlıca nötrofiller, daha az eozino- 
filler ve mononükleer fagositler olmak üzere lökositlerin mikroorganizmaları öldürmesini aktive eder (20). Ayrıca mononükleer fagosit ve vasküler endotelin IL-1 ve IL-6; hepatositlerin ise serum amiloid A, C-reaktif protein, C3 ve $\alpha_{2}$ makroglobulin gibi akut faz proteinlerini sentezlemesini uyarır (21). TNF- $\alpha$ ve IL-1'in IL- 6'nın ortamda varl-ğı durumunda ona tepki olarak sentezlerinin indirgenmesi oldukça önemlidir $(22,23)$.

Çalışmamızda tüm grupların asit ve serum TNF- $\alpha$ düzeylerine bakıldığı zaman, grup 3'ün asitteki TNF- $\alpha$ düzeyinin, steril asitli gruba (grup 1) göre anlamlı yüksek çıktığı görülürken, grup 2 ile, 1 ve 3 . gruplar arasında anlamlı bir fark saptanmadı. Serumdaki TNF- $\alpha$ seviyeleri ise hiçbir grup arasında istatistiksel anlamda bir farklılık göstermiyordu.

Rodriguez-Ramos ve arkadaşları'nın yaptığı çalışmada, spontan asit enfeksiyonu olan hastaların serum ve asit sıvısındaki TNF- $\alpha$ seviyesi steril asitli grubun değerlerine göre belirgin olarak yüksek saptanmıştı. Ancak aynı çalışmada, SBP grubu ile, KNNA grubu karşılaştırıldığında, iki grup arasında ne serum ne de asit sIVISı TNF- $\alpha$ düzeyleri farklılık arzetmiyordu (13). Bizim çalışmamızda ortaya çıkan sonuçlar, kısmen de olsa bu çalışma ile benzer yönler taşıyordu.

Navasa ve arkadaşları da, aynı şekilde spontan asit enfeksiyonu olan grubun asit sIvısı ve serumdaki TNF- $\alpha$ konsantrasyonlarını, steril asitli grubunkilere göre anlamlı derecede yüksek bulsa da (14), hem bizim hem de Rodriguez-Ramos ve arkadaşları (13)'nın yaptığı çalışmadan farklı olarak, SBP'li hastaların asit sıvısındaki TNF- $\alpha$ düzeyini KNNA grubununkinden anlamlı yüksek bulmuşlardır. İspanya'da yapılan bir çalışmada ise, sadece serumdaki TNF- $\alpha$ seviyesi, spontan asit enfeksiyonlu grupta belirgin yüksek iken, asit sıvısında steril asitli grupla benzer bir düzey elde edilmiştir (15).

Literatürdeki çalışmalara genel olarak bakıldığında, TNF- $\alpha$ açısından çelişkili sonuçlar ortaya çıkmaktadır. Bizim çaIışmamızda, SBP'li grubun asit sıvısındaki TNF- $\alpha$ seviyesi, steril asitli gruba göre yüksek çıkarken, KNNA'lı grup ile steril asitli grup arasındaki fark anlamlı saptanmamıştır. Biz bu durumun, KNNA'lı gruptaki etken mikroorganizma konsantrasyonun, SBP'li gruba göre çok daha düşük olmasından kaynaklanmış olabileceğini düşündük. Serumdaki TNF- $\alpha$ düzeylerinin ise hiçbir grup arasında anlamlı bir farklılık göstermemesini ise, daha önce de bahsedildiği üzere, IL-6'nın antiinflamatuvar etkilerinden olan, yüksek IL-6 konsantrasyonlarına sekonder TNF- $\alpha$ üretiminin baskılanmasına bağladık (23). Bunlarla birlikte, SBP'li grupta, aynen IL- 6 'da olduğu gibi, TNF- $\alpha$ seviyesinin asit ve serumdaki değerlerinin birbiriyle korele olduğunu gördük.
Nitrik oksit, L-arjinin'den nitrik oksit sentaz (NOS) tarafından sentezlenen kısa ömürlü bir radikaldir. NOS enziminin makrofajlardaki izoformu indüklenebilir iNOS'tur. Ilk olarak 1991'de Vallance ve Moncado, vasküler endotelde sentezlenen ve salgılanan vazodilatatör faktör olan NO'nun sirozun kardiyovasküler komplikasyonlarında rol oynadığını iddia etmişlerdir (24). O tarihten bu yana NO'nun siroz ve portal hipertansiyondaki rolü hem hayvan modellerinde hem de insanlarda araştırma konusu olmuştur. Bu nedenle, SBP'li hastalarda NO sentezinin artması gerektiği düşünülmüştür. Fakat şu ana kadar yapılan çalışmalarda birbiriyle çelişen sonuçlar elde edilmiştir.

Biz de çalışmamızda, asitli siroz hastalarını, steril asitli grup, KNNA'lı ve SBP'li grup olarak üçe ayırdıktan sonra, asitteki NO seviyesi açısından her grubu karşılaştırmayı ve spontan asit enfeksiyonunun tanısında, NO düzeyinin belirleyici olup olamayacağını görmek istedik. Sonuçta, beklediğimizin aksine, üç grup arasında da istatistiksel anlamda belirgin bir fark olmadığını tespit ettik.

Garcia-Tsao ve arkadaşları, dekompanse kronik karaciğer parankim hastalarında yaptıkları çalışmada, asit sıvısında enfeksiyon varlığında, NO üretimini araştırmışlar ve steril grupla spontan asit enfeksiyonlu grup arasında, asitteki NO seviyeleri arasında anlamlı bir fark saptamamışlardır. Ayrıca, spontan asit enfeksiyonlu grupta tedavi sonrası bakılan NO seviyelerinin de, tedavi öncesinden farksız olduğunu görmüşlerdir (25). Bu araştırmanın, bizim çaışmamızla bir diğer benzer yönü, SBP'li grup ile KNNA'lı grubun asit sıvısı NO düzeylerinin de birbirinden istatistiksel olarak farksız olmasıdır.

Fransa'da yapılan bir araştırmada, Bories ve arkadaşları, alkolik sirozlu hastalarda yaptıkları çalışmada, spontan asit enfeksiyonu olan grup ile stabil durumda olan siroz hastalarını karşılaştırdıklarında, serum NO seviyesinin, enfekte asitli grupta belirgin olarak daha yüksek olduğunu görmüşlerdir. Ayrıca asit sıvısındaki NO düzeyini serumdakinden yüksek saptayan araştırıcılar, bunu NO'nun periton boşluğundaki lokal üretimine bağlamışlardır (26).

Such ve arkadaşları, hastaneye başvuru sırasında steril asitli olan siroz hastalarından, daha sonra nazokomial SBP gelişenlerle, steril kalanları, serum ve asit sıvısındaki sitokin düzeyleri ve $\mathrm{NO}$ açısından karşılaştırmışlar ve başvuru anındaki serum ve asit NO seviyeleri açısından, iki grup arasında anlamlı bir fark saptamamışlardır (15). İspanya'da yapılan bir başka çalışmada, Jimenez ve arkadaşları, dekompanse kronik karaciğer parankim hastalığı nedeniyle izlenen hastalarda, spontan asit enfeksiyonu olanların asit sıvısındaki NO seviyesini steril asitli gruba göre belirgin yüksek bulmuşlardır (16). Bu çalışmada da, Bories ve arkadaşları'nın (26) araştırmasıyla uyumlu şekil- 
de, tedavi süresince asitteki NO seviyelerinin arttığı saptanmıştır. Araştırııılar bunu, inflamatuvar ve immünolojik bir uyaranla karşılaştıktan sonra, peritoneal makrofajlardaki nitrik oksit sentaz ekspresyonunun 4 gün ve hatta daha fazla bir süre boyunca devam etmesine bağlamışlardır (27). Vallance ve Moncada, iNOS enziminin artmış ekspresyonunun endotoksemi ile ilişkili olabileceğini ileri sürmüşlerdir (24). Bu düşünce doğrultusunda, Guarner ve arkadaşları, sirozlu hastalarda plazma endotoksin ve serum NO düzeylerini ölçmüşler ve kontrol grubuna göre sirozlu hastaların belirgin şekilde yüksek NO seviyelerine sahip olduklarını doğrulamışlardır (28).

Biz çalışmamızda, steril asitli grup, KNNA'ı ı ve SBP'li grupları birbiriyle ayrı ayrı karşılaştırdık ve gruplar arasında anlamlı bir fark olmadığını gördük. Burada, hastaların nitrit ve nitrat seviyelerini etkileyebilecek gıdalar tüketip tüketmediği kontrolümüz dışında olan bir durumdu, çünkü hastalar kliniğe kabul edildikten hemen sonra belli bir süre aç kalmaları bile beklenmeden asit sıvıları alınıyor ve spontan asit enfeksiyonu şüphesi olanlara derhal antibiyoterapisi başlanıyordu. Bu yüzden protein içeriği yüksek olan nitrat ve nitrit seviyelerini etkileyebilecek gıdaların, sonuçları az da olsa etkilemiş olabileceği göz önüne alınmalıdır.

Myeloperoksidaz, fagositik hücrelerde bulunan bir enzimdir (29). PNL'nin azurofil granüllerinde fazla miktarda bulunur (30). Bu yüzden MPO aktivitesinin ölçümü dokuya PNL toplanmasını göstermede oldukça yararlıdır (30). Literatüre baktığımızda, siroz hastalarında MPO ile ilgili yapılmış çok az çalışma bulunmaktadır. Nakamuta

\section{KAYNAKLAR}

1. Filik L, Unal S. Clinical and labaratory features of spontaneous bacterial peritonitis. East Afr Med J 2004;81:474-9.

2. Such J, Runyon BA. Spontaneous bacterial peritonitis. Clin Infect Dis 1988;27:669-74.

3. Tilg H, Diehl AM. Cytokines in alcholic and nonalcoholic steatohepatitis. N Engl J Med 2000;343:1467-76.

4. Gabay C, Kushner I. Acute-phase proteins and other systemic responses to inflammation. N Engl J Med 1999;340:448-54.

5. Cortas NK, Wakid NW. Determination of inorganic nitrate in serum and urine by a kinetic cadmium-reduction method. Clin Chem 1990;36:1440-3.

6. Byl B, Roucloux I, Crusiaux A, Dupont E, Deviere J. Tumor necrosis factor $\alpha$ and interleukin 6 plasma levels in infected cirrhotic patients. Gastroenterelogy 1993;104:1492-7.

7. Nussler AK, Di Silvio M, Billiar TR, et al. Stimulation of the nitirc oxide synthase pathway in human hepatocytes by cytokines and endotoxin. J Exp Med 1992;176:261-4.

8. Tilg $\mathrm{H}$, Wilmer $\mathrm{A}$, Vogel $\mathrm{W}$, et al. Serum levels of cytokines in chronic liver diseases. Gastroenterology 1992;103:264-74.

9. Nakamuta M, Ohashi M, Tanabe Y, Hiroshige K, Nawata H. High plasma concentration of myelopeeroxidase in cirrhosis: a possible marker of hypersplenism. Hepatology 1993;18:1377-83. ve arkadaşları, sirozlu hastalarda yaptıkları bir çalışmada, plazma MPO konsantrasyonlarını kronik hepatitlilere ve sağlıklı kontrol grubuna göre daha fazla saptamışlardır (9). Yao ve arkadaşları, zymosan ile peritonit geliştirilen ratların asit sıvılarında MPO aktivitesinin arttığını göstermişlerdir (31). Çalışmamızda, asit sıvısı MPO düzeyleri açısından steril asitli grup ile KNNA ve SBP gruplarını ayrı ayrı karşılaştırdığımızda, her iki grubun MPO seviyelerinin, steril asitli gruptan anlamlı şekilde yüksek olduğunu gördük. KNNA grubu ile SBP grubu arasında ise belirgin bir fark olmadığını saptadık. MPO düzeyinin, asit enfeksiyonu yönünden pozitif prediktif değerini \%50 (özgüllük $\% 85$, duyarlılık \%100) olarak belirledik. IL-6 ile karşılaştrıldığında, asit enfeksiyonunun tespitinde MPO'nun aynı derecede duyarlı, özgüllüğünün ise biraz daha fazla olduğunu gördük. Bu bulgular çerçevesinde, asit sIVISI MPO düzeylerinin, spontan asit enfeksiyonu açısından anlamlı olduğu ve tanısal açıdan konvansiyonel yöntemlere yardımcı olabileceği sonucuna vardık.

Sonuç olarak bu bulgular, dekompanse/asitli kronik karaciğer parankim hastalarında, spontan asit enfeksiyonunun gidişi ve tanısı açısından, özellikle kültür negatif nötrositik asitli olgularda, asit sIVISI ve serum IL-6 ve asit MPO düzeylerinin, özgüllüğü nispeten düşük olmakla beraber duyarlıığının yüksek saptanması nedeniyle, başka bir enfeksiyon kaynağının olmadığı durumlarda, ölçümünün yararlı olabileceğini düşündürmektedir.

\section{"Tüm yazarlar herhangi bir çıkar çatışması olmadığı- nı beyan ederler."}

10. Gaut JP, Byun J, Tran HD, et al. Myeloperoxidase produces nitrating oxidants in vivo. J Clin Invest 2002;109:1311-9.

11. Strassmann G, Jacob CO, Evans R, Beall D, Fonq M. Mechanisms of experimental cancer cachexia. Interaction between mononuclear phagocytes and colon-26 carcinoma and its relevance to IL-6 mediated cancer cachexia. J Immunol 1992;148:3674-8.

12. Baykal Y. Antiinflamatuar sitokinler. GATA Bülteni 1998;40:113-7.

13. Rodriguez-Ramos C, Galan F, Diaz F, et al. Expression of pro-inflammatory cytokines and their inhibitors during the course of spontaneous bacterial peritonitis. Dig Dis Sci 2001;46:1668-76.

14. Navasa M, Follo A, Filella $X$, et al. Tumor necrosis factor and interleukin-6 in spontaneous bacterial peritonitis in cirrhosis: Relationship with the development of renal impairment and mortality. Hepatology 1998; 27:1227-32.

15. Such J, Hillebrand DJ, Guarner $C$, et al. Tumor necrosis factor- $\alpha$, interleukin-6, and nitric oxide in sterile ascitic fluid and serum from patients with cirrhosis who subsequently develop ascitic fluid infection. Dig Dis Sci 2000;46:2360-6.

16. Jimenez W, Ros J, Morales-Ruiz M, et al. Nitric oxide production and inducible nitric oxide synthase expression in peritoneal macrophages of cirrhotic patients. Hepatology 1999;30:670-6. 
17. Propst T, Propst A, Herold M, et al. Spontaneous bacterial peritonitis is associated with high levels of interleukin- 6 and its secondary mediators in ascitic fluid. Eur J Clin Invest 1993;23:832-6.

18. Zeni $F$, Tardy B, Vindimian $M$, et al. High levels of tumor necrosis factor- $\alpha$ and interleukin- 6 in the ascitic fluid of cirrhotic patients with spontaneous bacterial peritonitis. Clin Infect Dis 1993;17:21823.

19. Bac DJ, Pruimboom WM, Mulder PG, Zijlstra FJ, Wilson JH. High interleukin-6 production within the peritoneal cavity in decompensated cirrhosis and malignancy- related ascites. Liver 1995;15:26570 .

20. Aggarval BB, Kohr WS, Hass PE. Human tumor necrosis factor. J Biol Chem 1992;260:2345-54.

21. Arai K, Lee F, Miyajam A, Miyatake S, Arai N, Yokota T. Cytokines: Coordinators of immune and inflammatory responses. Ann Rev Biochem 1990;59:783-836.

22. Dinarello CA, Moldawer LL. Proinflammatory and anti-inflammatory cytokines in rheumatoid arthritis. Amgen Inc, USA 2000;3-79.

23. Schindler R, Mancilla J, Endres $S$, et al. Correlation and interactions in the production of interleukin-6 (IL-6), interleukin-1 (IL-1) and tumor necrosis factor (TNF) in human blood mononuclear cells: IL-6 suppresses IL-1 and TNF. Blood 1990;75:40-7.

24. Vallance $P$, Moncada S. Hyperdynamic circulation in cirrhosis: a role for nitric oxide? Lancet 1991;337:776-8.
25. Garcia-Tsao G, Angulo P, Garcia JC, Groszmann RJ, Cadelina G. The diagnostic and predictive value of ascites nitric oxide levels in patients with spontaneous bacterial peritonitis. Hepatology 1998;28:17-21

26. Bories PN, Campillo B, Azaou L, Scherman E. Long-lasting NO overproduction in cirrhotic patients with spontaneous bacterial peritonitis. Hepatology 1997;25:1328-33.

27. Nathan C, Xie QW. Regulation of biosynthesis of nitric oxide. J Biol Ghem 1994; 269:13725-8.

28. Guarner C, Soriano G, Tomas A, et al. Increased serum nitrite and nitrate levels in patients with cirrhosis: relationship to endotoxemia. Hepatology 1993;18:1139-43.

29. Schultz J, Cortin R, Oddi F, Kaminker K, Jones W. Myeloperoxidase of the leukocyte of normal blood. Arch Biochem Biophys 1965;111:73-9.

30. Krawisz JE, Sharon P, Stenson WF. Quantitative assay for acute intestinal inflammation based on myeloperoxidase activity. Gastroenterology 1984;87:1344-50.

31. Yao V, McCauley R, Cooper D, Platell C, Hall JC. Myeloperoxidase response to peritonitis in an experimental model. ANZ J Surg 2003;73:1052-6. 